\title{
DIAGNOSIS OF SOCIO-ECONOMIC DEVELOPMENT OF THE EUROPEAN UNION COUNTRIES
}

Katarzyna Cheba ${ }^{1}$, Assistant Professor; Iwona Bak, Associate Professor ${ }^{2}$

1,2 West Pomeranian University of Technology, Szczecin

\begin{abstract}
The main purpose of the paper is an assessment of current level of socio-economic development of EU countries. In situation of many difficult changes, which could complicate the further EU's situation, the analyses provided in these areas are important. Due to large differences in the social and economic development of EU countries, the multi-criteria taxonomy was used to compare the situation in both of these areas. The authors decided that the basis for the analyses will be the indicators transformed according to the relative taxonomy method. The results confirmed the relatively large differences between EU countries especially in the area of economic development.
\end{abstract}

Key words: socio-economic development, EU countries, multi-criteria taxonomy, relative taxonomy. JEL code: C38, P11, P36.

\section{Introduction}

In the literature, more and more opinions appear that the socio-economic level of development of EU countries becomes similar (Rodriguez-Pose, 1999; Ray, 2000). At the same time, the existence of differences in the development of countries belonging to this political and economic partnershiptype is increasingly emphasized by many other authors (Bilbao-Osorio and Rodriguez-Pose, 2004). These differences are mainly observed when the countries located in Southern and Eastern Europe are compared to countries from North and West. According to Podkaminer (2013), the relative backwardness of the countries of Central and Eastern Europe have deep historical roots. Whereas the crisis from 2007-2008 had the greatest impact on the difficult current situation of the countries of Southern Europe. The most differences are visible between their levels of development in economic area, while in the social ones they seem to be smaller (Bak and Cheba, 2018a). Now in a situation of many difficult changes which could complicate the EU's ability to deal with multiple internal and external challenges such as: the pending departure of the United Kingdom (UK) from the EU (Brexit), migration and related societal integration concerns, and a heightened terrorism threat, some authors (CRS Report, 2018) are questioning the future shape and character of the EU. In this context, the analyses of the current level of development of EU countries are relevant. Their aim is to indicate the most visible differences between more and less developed countries. These differences have also a strong impact on the other areas of EU development. The literature (Hopwood et al., 2005; SzopikDepczynska et al., 2018; Bak and Cheba, 2018b) emphasizes that the most economically developed countries also have the biggest influence on negative changes in the natural environment, but this connection isn't observed in the case of Scandinavian countries. Their economic development is related to the positive impact on the natural environment and quality of human life.

The aim of the study is an assessment of current level of socio-economic development of EU countries, both in each group of this development, separately and together. The article attempts to find the main reasons of the differences between the analysed countries in the discussed areas. The paper is divided into 5 sections. The first presents the aim of the research. Next, the mathematical research method is presented. The third one is dedicated to a presentation of the statistical data. The fourth section presents the research results and discussion, and the last one contains conclusions. The added value of the paper is a division into groups of EU countries according their

\footnotetext{
katarzyna.cheba@zut.edu.pl 
socio-economic level of development, but each of these areas is analysed separately. It means that comparable will be these countries which level of development will be both similar in socio- and economic areas.

\section{Description of the research methods}

In the paper to study the disparities between the European Union countries in the field of socioeconomic development the multi-criteria taxonomy was used. The basis of the results analyses was the indicators transformed according to the relative taxonomy method. In the relative taxonomy, it is assumed that all indicators should have a positive interpretation when assessing the position of a given country against the background of others (Wydymus, 2013, p. 634). It means that all destimulatns have to be transformed into stimulants as follows: The work assumes that if the $X^{\prime}{ }_{k}$ is a destimulant, then the $X_{k}$ will be a stimulant after the transformation: $X_{i k}=1 / X_{i k}^{\prime}$. Data analysis based on this method takes place in several stages. In the first one the relativization the values of diagnostic features is made as follows:

$$
\mathrm{d}_{(/ / \mathrm{i}) \mathrm{jt}}=\mathrm{x}_{\mathrm{ljt} / \mathrm{x}} \mathrm{x}_{\mathrm{ijt}}(1)
$$

where: $d$ - relativized values of the indicators, $i, l=1, \ldots, k$-objects' numbers, $i \neq l, j=1, \ldots, m$ - numbers of sub-indicators, $t=1, \ldots, n$ - numbers of years.

The relative taxonomic measure of development is estimated as follows:

$$
\mu_{\mathrm{it}}=\left[\Sigma 1 / \mathrm{w}_{\mathrm{ijt}} \mathrm{]} / \mathrm{m}(2)\right.
$$

The description of every stage of this method and their application in the economic analyses were presented in the following papers: Wydymus (2013), Lira (2015), Cheba (2019). It should be noted that this measure is close to 1 and can be interpreted as the relative position of the object relative to all other analyzed objects (in this case: countries). For objects with a similar level of development, the values generally hover around unity. The lower the value of the measure, the better the situation of the object (country) against the background is. Objects can also be divided into typological classes with similar levels of development. The first class contains the best countries, while the fourth the worst ones. To the second class countries with value of taxonomic measure of development above mean value for all groups were assigned. To the third class these ones with the values of this measure below mean value. The results of the relative transformation of indicators were used in the next stage to compare the EU countries according their socio- and economic development. For this purpose, the multi-criteria taxonomy was applied. In this method the following procedure is required (Nowak, 1990; Malina, 2004):

1) In the first step $D^{K}$ distance matrices (based on Euclidean distance) are defined for each of the distinguished classification criteria of $K_{l}(l=1, \ldots, r)$.

2) A threshold value is defined for distance $d^{*}$. The value is usually defined in accordance with the following formula:

$$
d^{*}=\min _{i} \max _{j}\left\{d_{i j}\right\}
$$

3) For each classification criterion, $\mathbf{C}^{\mathbf{K}}$ affinity matrix of $(n \times n)$ dimension is defined, whose elements $c_{i j}^{K}(i, j=1, \ldots, n)$ are equal to: 


$$
c_{i j}^{K}=1 \text { for } d_{i j} \leq d^{*}
$$

$$
c_{i j}^{K}=0 \text { for } d_{i j}>d^{*}
$$

If inequality $d_{i j} \leq d^{*}$ is satisfied, the objects designated as $i$ and $j$ are deemed as similar in terms of the examined criterion, if, however, an opposite condition is satisfied, the relevant objects are treated as dissimilar for value $d^{*}$, thus the affinity measure of $c_{i j}$ will equal zero.

4) A final $\mathbf{C}_{(\mathrm{n} \times \mathrm{n})}$ affinity matrix is determined among the analysed units. $c_{i j}$ elements of $\mathbf{C}$ matrix are equal to the product of relevant elements of $\mathbf{C}^{\mathbf{K}}$ matrix for all the analysed criteria, i.e.:

$$
c_{i j}=\prod_{K=1}^{r} c_{i j}^{K}
$$

It means that $c_{i j}=1(i, j=1, \ldots, n)$, if each of $c_{i j}^{K}$ elements corresponding to it in $\mathbf{C}^{\mathbf{K}}$ matrices is equal to one, and $c_{i j}=0$, if at least one of the $c_{i j}^{K}$ elements corresponding to it is equal to zero. According to the above, two objects are considered to be similar to one another simultaneously on account of all the criteria, if they are similar to one another separately on account of those individual criteria. The adoption of a given algorithm may lead to determining a large number of small sized groups (one- and two-elements groups), (Malina, 2004).

\section{Statistical materials}

To assess the socio-economic development of EU countries, statistical data from 2016 presented by Eurostat were collected. Because analyses presented in the paper are a part of larger research including data from 2008 to 2016, Croatia which became EU member in 2010, wasn't included in this research. To eliminate the diagnostic features with the similar potential of information, the method of the inverted matrix of correlation coefficients in each group of indicators was applied. Finally, to the set of diagnostic features in the economic area 14 indicators divided into following groups: economic development ( 5 indicators), employment and conditions of work ( 5 indicators), innovations ( 2 indicators), and sustainable production patterns ( 2 indicators) were selected. The second group was described by 17 indicators, which can be assigned to the following fields: poverty and social exclusion ( 7 indicators), lifestyle and public health ( 3 indicators), education and development (3 indicators), level and quality of life ( 2 indicators), public safety ( 2 indicators).

\section{Research results and discussion}

At first the results of the relative taxonomy method were presented (Table 1). As a result of the use of this method a ranking of $27 \mathrm{EU}$ countries in which the impact on the assessment of the country has an effect not only on its own situation but also the situation of the other states was obtained. In many of the analysed cases, visible changes in the position taken by individual EU countries in the ranking between the socio- and economic areas were observed. Significant changes in the ranking (significant changes were recognized by at least 5 items) can be seen for: Belgium ( 7 position in economic development and 15 in social development), Germany (3 and 13), Greece (18 and 27), Italy (13 and 22), Lithuania (15 and 23). Whereas opposite changes (lower position in economic development and higher in social area) in the case of following countries can be observed: Cyprus (22 and 14), Finland (8 and 2), Ireland (14 and 7), Luxembourg (26 and 5), Malta (27 and 11), Poland (24 and 18 ). The first places in both rankings were occupied by the Scandinavian countries: 
Sweden, Denmark and Finland. The similar level in both socio- and economic development can be observed in the case of: Portugal (20 position in both classifications) and Spain (17). The lowest positions of countries located in the Southern and Eastern Europe are worth drawing attention to.

The reverse situation was recorded in the countries of Northern and Western Europe.

Table 1

\section{Classification of EU countries - the relative taxonomy method}

\begin{tabular}{|c|c|c|c|c|c|c|}
\hline \multirow[b]{2}{*}{ Countries } & \multicolumn{3}{|c|}{ Economic development } & \multicolumn{3}{|c|}{ Social development } \\
\hline & $\begin{array}{l}\text { Value of } \\
\text { measure }\end{array}$ & Position & $\begin{array}{l}\text { Typological } \\
\text { group }\end{array}$ & $\begin{array}{l}\text { Value of } \\
\text { measure }\end{array}$ & Position & $\begin{array}{c}\text { Typological } \\
\text { group }\end{array}$ \\
\hline Austria & 0.7012 & 5 & II & 0.7291 & 3 & II \\
\hline Belgium & 0.7369 & 7 & II & 0.9307 & 15 & II \\
\hline Bulgaria & 1.3388 & 23 & III & 1.6246 & 25 & IV \\
\hline Cyprus & 1.2606 & 22 & III & 0.9299 & 14 & II \\
\hline Czech Republic & 0.7997 & 10 & II & 0.7836 & 9 & II \\
\hline Denmark & 0.5323 & 1 & I & 0.7304 & 4 & II \\
\hline Estonia & 1.0812 & 19 & III & 1.2039 & 21 & III \\
\hline Finland & 0.7538 & 8 & II & 0.7025 & 2 & II \\
\hline France & 0.7819 & 9 & II & 0.7868 & 10 & II \\
\hline Germany & 0.5816 & 3 & II & 0.8515 & 13 & II \\
\hline Greece & 1.0638 & 18 & III & 1.8670 & 27 & IV \\
\hline Hungary & 0.9982 & 16 & II & 1.0809 & 19 & III \\
\hline Ireland & 0.9830 & 14 & II & 0.7571 & 7 & II \\
\hline Italy & 0.9589 & 13 & II & 1.2117 & 22 & III \\
\hline Latvia & 1.2006 & 21 & III & 1.4657 & 24 & IV \\
\hline Lithuania & 0.9977 & 15 & II & 1.3325 & 23 & III \\
\hline Luxembourg & 1.8043 & 26 & IV & 0.7470 & 5 & II \\
\hline Malta & 2.9163 & 27 & IV & 0.7956 & 11 & II \\
\hline Netherlands & 0.6049 & 4 & II & 0.7565 & 6 & II \\
\hline Poland & 1.3443 & 24 & III & 1.0443 & 18 & III \\
\hline Portugal & 1.1382 & 20 & III & 1.1465 & 20 & III \\
\hline Romania & 1.6911 & 25 & IV & 1.7105 & 26 & IV \\
\hline Slovakia & 0.9367 & 12 & II & 1.0022 & 16 & II \\
\hline Slovenia & 0.8891 & 11 & II & 0.8248 & 12 & II \\
\hline Spain & 1.0301 & 17 & II & 1.0077 & 17 & II \\
\hline Sweden & 0.5696 & 2 & I & 0.7013 & 1 & II \\
\hline United Kingdom & 0.7317 & 6 & II & 0.7709 & 8 & II \\
\hline
\end{tabular}

Source: author's calculations

In the next step the EU countries were divided into groups taking into account their results both in socio- and economic development. For this purpose, the multi-criteria taxonomy method was used. As a result of application of this method 6 following groups were created: a) group I: Austria, Belgium, the Cyprus, the Czech Republic, Denmark, Finland, France, Germany, Hungary, Ireland, Italy, Latvia, Lithuania, Luxembourg, the Netherlands, Poland, Portugal, Slovakia, Slovenia, Sweden, the United Kingdom, b) group II: Bulgaria, Romania, c) group III: Estonia, d) group IV: Greece, e) group V: Spain, f) group VI: Malta. The first group including 21 countries was the largest. To the second group only 2 countries located in Southern Europe were jointed. These countries became a part of EU in 2007. Whereas the next four groups formed one-element clusters. It is worth noticing that sometimes, even one indicator was decisive for belonging to a particular group. Due to this, it 
was decided to determine the measure that can be interpreted as the weights defining the relative importance of individual indicator (Nowak, 1990):

$$
\omega_{j}=V_{j} / \Sigma V_{j} \cdot 100 \%(7)
$$

where: $V_{j}$ - classic coefficient of variation calculated for the $j$-th diagnostic feature.

It turned out that the most important are the following indicators: from the group of poverty and social exclusion: a) self-reported unmet need for medical care by detailed reason (too expensive or too far to travel or waiting list), \% of population aged 16 and over - with the value of the relative importance on the level $7.29 \%$, b) population unable to keep home adequately warm by poverty status, $\%$ of population $-5.97 \%$, c) overcrowding rate by poverty status, $\%$ of population $-5.04 \%$ next from the group of lifestyle and public health: d) death rate due to homicide, number par 100 000 persons - $5.71 \%$, and from economic development; e) government support to agricultural research and development, euro per inhabitant $-5.20 \%$. Three of these indicators (their mean values in the indicated groups) were presented on the Fig. 1-3.

Detailed analysis of the mean level of indicators in individual groups may explain the reasons for including such many EU countries to the first typological group. Their membership in the same group was caused by the value of indicators close to the mean value for a whole group. The results obtained are also confirmed by the conclusions formulated by other authors (Eagle et al., 2010). Such a large first group shows that in the area of socio-economic development, the majority of EU countries obtain similar results. On the other hand, among the 27 analysed countries, there are also those whose results differ significantly from mean value in group both in plus and in minus.

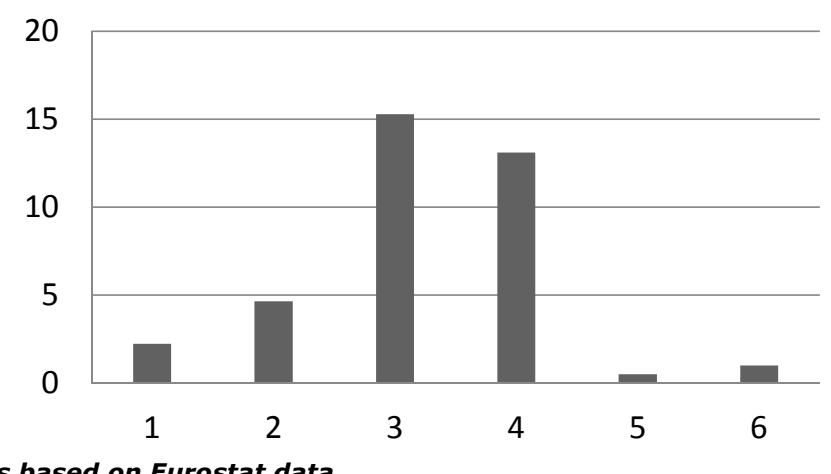

Source: author's calculations based on Eurostat data

Fig. 1. The mean value in groups of indicator describing the size of population unable to keep home adequately warm by poverty status ( $\%$ of population)

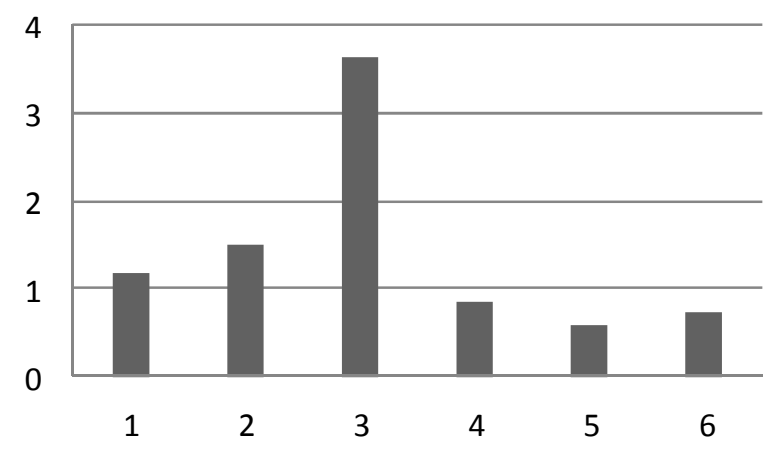

Source: author's calculations based on Eurostat data

Fig. 2. The mean value in groups of indicator describing the level death rate due to homicide (number par 100000 persons) 


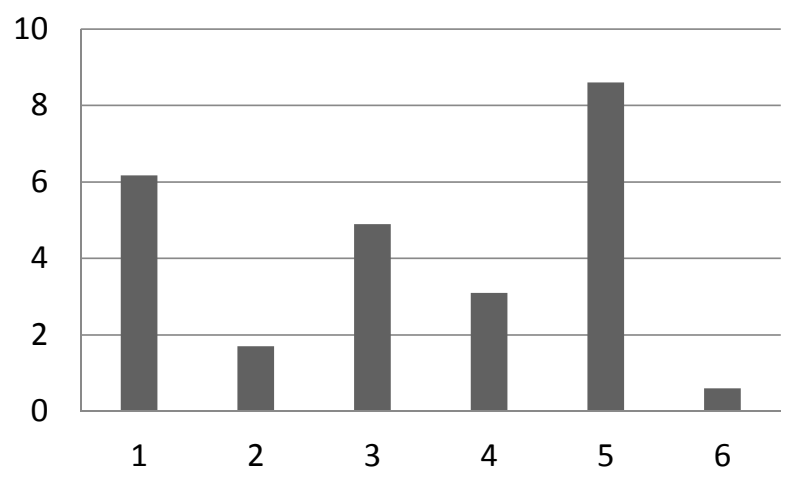

Source: author's calculations based on Eurostat data

Fig. 3. The mean value in groups of indicator describing government support to agricultural research and development (euro per inhabitant)

The main reason of belonging of EU countries to the second group was a quite lower level of such indicators as: a) agricultural factor income per annual work unit (AWU) (source: EC services), chain linked volumes, b) real GDP per capita, chain linked volumes (2010), euro per capita, c) employment in high- and medium-high technology manufacturing sectors and knowledge-intensive service sectors, \% of total employment, d) tertiary educational attainment, \% of population aged 30 to 43 , e) adult participation in learning by sex, \% of population aged 25 to 73 . They are very important indicators which describe the area of economic development. In the literature (Bilsen and Konings, 1998; Cheba, 2019) Bulgaria and Romania are indicated as the least developed countries in EU. It is not surprising that they belong to a separate group. Separation of Estonia as a one-element group was caused by a very high level of such indicators as: a) area under organic farming, \% of utilised agricultural area (UAA), b) people killed in accidents at work, number per 100000 employees, c) suicide rate by sex, number per 100000 persons, d) self-reported unmet need for medical care by detailed reason (too expensive or too far to travel or waiting list), \% of population aged 16 and over, e) death rate due to homicide, number par 100000 persons. In addition, this country was characterized by the lowest values of the following indicators: a) volume of freight transport relative to GDP, index $(2005=100)$, b) general government gross debt, percentage of gross domestic product (GDP), c) people living in households with very low work intensity, percentage of total population aged less than 78, d) population unable to keep home adequately warm by poverty status, $\%$ of population, e) population reporting occurrence of crime, violence or vandalism in their area by poverty status, $\%$ of population.

In the case of Greece, compared to the EU average, this country can be positively assessed due to: a) inactive population due to caring responsibilities by sex, \% of inactive population aged 20 to 73, b) people killed in accidents at work, number per 100000 employees, c) suicide rate by sex, number per 100000 persons. While such indicators as: a) young people neither in employment nor in education and training by sex, \% of population aged 15 to $38, \mathrm{~b}$ ) general government gross debt, percentage of gross domestic product (GDP), c) population unable to keep home adequately warm by poverty status, $\%$ of population, d) long-term unemployment rate by sex, $\%$ of active population, indicate not so good situation in this country. In many papers (Hadjimichalis, 2011), Greece and other countries located in the south of Europe are indicated as a region in which the negative impact of the crisis from 2007-2008 can be observed. This impact seems to be noticed also in the research results presented in this work. According to authors it is also one of the most important factors influencing the current level of development of these countries. 
About separation of Spain as one-element cluster decided a quite good situation described by the following indicators: a) death rate due to homicide, number par 100000 persons, b) people killed in road accidents (source: EC services), rate, c) self-reported unmet need for medical care by detailed reason, (too expensive or too far to travel or waiting list), \% of population aged 16 and over.

In the case of Malta, it is worth paying attention to a quite good social situation related to the lowest values of such indicators as: a) overcrowding rate by poverty status, $\%$ of population, b) relative median at-risk-of-poverty gap, $\%$ distance to poverty threshold, c) long-term unemployment rate by sex, \% of active population, d) population living in a dwelling with a leaking roof, damp walls, floors or foundation or rot in window frames of floor by poverty status, $\%$ of population. In comparison with the average in EU the values of these indicators for Malta are the best. Malta also stands out positively due to the level of employment in high- and medium-high technology manufacturing sectors and knowledge-intensive service sectors ( $\%$ of total employment).

The results of classification of EU countries (countries in first group and others) are also presented on the map (Fig. 4).

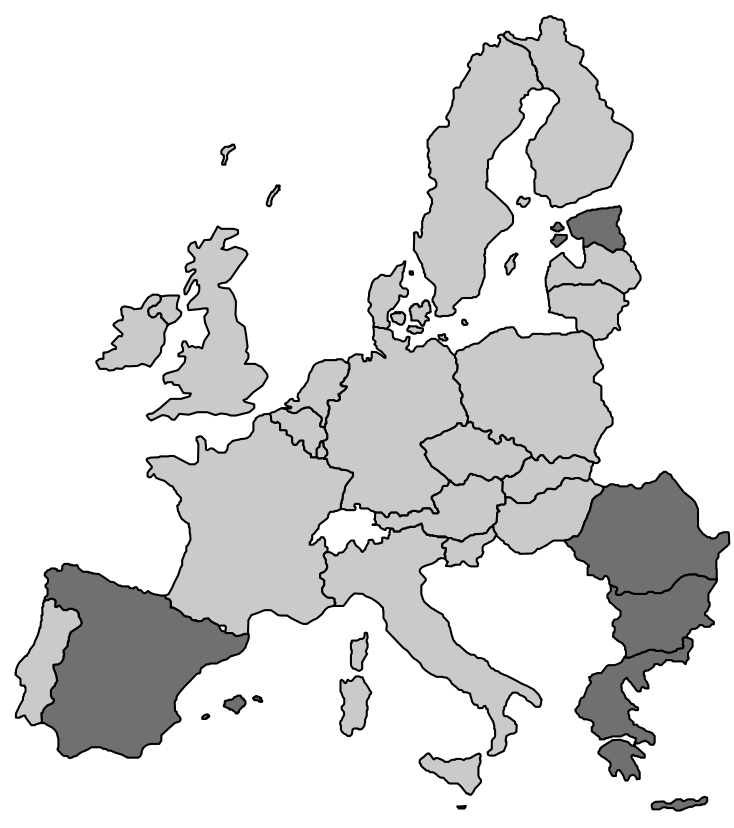

Source: author's calculations based on Eurostat data
Group 1

other groups

Fig. 4. The division into group of EU countries according their level of socio- and economic development

\section{Conclusions}

1) Diagnosis of the socio-economic situation of EU countries was formulated on the basis of rankings and the characteristics of the separated typological groups. Studies confirmed the differences between these countries both in social and economic area. Monitoring this diversification is very important as too large disproportions in the level of development of individual countries have a negative impact on the development of the EU in larger context.

2) In effect of application of the multi-criteria taxonomy, it was possible to distinguish typological groups of countries similar to each other in terms of both aspects (social and economic). To the same largest group (first group) were assigned countries which seem to have a different socio- 
economic situation. However, the obtained results were justified by detailed analysis of both the value of the relative taxonomic measure of development and the importance of diagnostic features and their mean level in individual groups. The research shows that for most countries their socioeconomic situation does not differ significantly from the mean of EU level.

3) A great difficulty in conducting statistical multidimensional analyses is the collection of reliable and comparable statistical data. It turns out that the databases of statistical offices of EU countries do not always provide full and up-to-date information.

\section{Bibliography}

1. Bak, I., Cheba, K. (2018a). Study of Spatial Uniformity of Sustainable Development of the European Union Before, During and After the Economic Crisis. Przeglad Statystyczny 2, pp. 222-246.

2. Bak, I., Cheba, K. (2018b). The Application of the Dynamic Classifications in Order to Evaluate the Changes of the European Union's Sustainable Development. Proceedings of the 2018 International Conference "ECONOMIC SCIENCE FOR RURAL DEVELOPMENT", Jelgava.

3. Bilbao-Osorio, B., Rodríguez-Pose, A. (2004). From R\&D to Innovation and Economic Growth in the EU. $A$ Journal of Urban and Regional Policy 35(4), pp. 434-455.

4. Bilsen, V., Konings, J. (1998). Job Creation, Job Destruction, and Growth of Newly Established, Privatized, and State-Owned Enterprises in Transition Economies: Survey Evidence from Bulgaria, Hungary, and Romania. Journal of Comparative Economics 26(3), pp. 429-445.

5. Cheba, K. (2019). Zrownowazona Konkurencyjnosc Krajow Unii Europejskiej. Studia LiteraturowoEmpiryczne. CeDeWu, in press.

6. CRS Report. (2018). The European Union: Ongoing Challenges and Future Prospects. Congressional Research Service R44249. www.crs.gov.

7. Eagle N., Macy, M., Claxton, R. (2010). Network Diversity and Economic Development, Science 21, pp. 1029-1031.

8. Hadjimichalis, C. (2011). Uneven Geographical Development and Socio-Spatial Justice and Solidarity: European Regions After the 2009 Financial Crisis. European Urban and Regional Studies 18(3), pp. 254-274.

9. Hopwood, B., Mellor, M., O'Brien, G. (2005). Sustainable Development: Mapping Different Approaches, Sustainable Development, No. 13(1), pp. 38-52.

10. Lira, J. (2015). A Comparison of the Methods of Relative Taxonomy for the Assessment of Infrastructural Development of Counties in Wielkopolskie Voivodeship. Quantitative Methods in Economics XVI(2), pp. 5362.

11. Malina, A. (2004). Wielowymiarowa Analiza Przestrzennego Zroznicowania Struktury Gospodarki Polski Wedlug Wojewodztw. Wydawnictwo AE w Krakowie, Krakow.

12. Nowak, E. (1990). Metody Taksonomiczne w Klasyfikacji Obiektów Społeczno-Gospodarczych. Warszawa: PWE.

13. Podkaminer, L. (2013). Development Patterns of Central and East European Countries (in the Course of Transition and Following EU Accession). Research Reports 388, The Vienna Institute for International Economic Studies.

14. Ray, C. (2000). Endogenous Socio-Economic Development in the European Union - Issues of Evaluation. Journal of Rural Studies 16(4), pp. 447-458.

15. Rodríguez-Pose, A. (1999). Convergence or Divergence? Types of Regional Responses to Socio-Economic Change in Western Europe. Journal of Economic and Social Geography 90(4), pp. 365-378.

16. Szopik-Depczynska, K., Cheba, K., Bak, I., Stajniak, M., Simbolid, A., Ioppolo, G. (2018). The Study of Relationship in a Hierarchical Structure of EU Sustainable Development Indicators. Ecological Indicators, 90, pp. 120-131.

17. Wydymus, S., (2013). Economic Development and Income Level in UE Countries - Taxonomic Analysis, Zeszyty Naukowe Uniwersytetu Szczecinskiego 756, Finanse, Rynki Finansowe, Ubezpieczenia 57, pp. 632645. 